\title{
European population trends and current conservation status of an endangered steppe-bird species: the Dupont's lark Chersophilus duponti
}

\author{
Julia Gómez-Catasús Corresp., ${ }^{1}$ ， Cristian Pérez-Granados ${ }^{1,2}$ ， Adrián Barrero ${ }^{1}$ ， Gerard Bota ${ }^{3}$, David Giralt ${ }^{3}$, \\ Germán M. López-Iborra $^{2}$ ， David Serrano ${ }^{4}$ ， Juan Traba ${ }^{1}$ \\ ${ }^{1}$ Terrestrial Ecology Group (TEG-UAM), Department of Ecology, Universidad Autónoma de Madrid, Madrid, Spain \\ 3 Biodiversity and Animal Conservation Lab, Forest Sciences Center of Catalonia (CTFC), Solsona, Catalonia, Spain \\ 4 Department of Conservation Biology, Estación Biológica de Doñana (EBD-CSIC), Sevilla, Spain \\ Corresponding Author: Julia Gómez-Catasús \\ Email address: julia.gomez@uam.es
}

\section{Background}

Steppe-birds face drastic population declines throughout Europe. The Dupont's lark Chersophilus duponti is an endangered steppe-bird species whose European distribution is restricted to Spain. This scarce passerine bird could be considered an 'umbrella species', since its population trends may reveal the conservation status of shrub-steppes. However, trends for the Spanish, and thus European, population of Dupont's lark are unknown.

In this work, we evaluated Dupont's lark population trends in Europe employing the most recent and largest compiled database to date (92 populations over 12 years). In addition, we assessed the species threat category according to current applicable criteria (approved in March 2017) in the Spanish Catalogue of Threatened Species (SCTS), which have never been applied to the Dupont's lark nor to any other Spanish species. Finally, we compared the resulting threat categories with the current conservation status at European, national and regional levels.

\section{Methods}

We fitted Switching Linear Trend models (software TRIM - Trends and Indices for Monitoring data) to evaluate population trends at national and regional scale (i.e. per Autonomous Community) during the period 2004 - 2015. In addition, the average finite annual rate of change $(\lambda)$ obtained from the TRIM analysis was employed to estimate the percentage of population size change in a 10-year period. A threat category was assigned following A1 and A2 criteria applicable in the SCTS.

\section{Results}

Trends showed an overall 3.9\% annual decline rate for the Spanish population (moderate decline, following TRIM). Regional analyses showed high inter-regional variability. We forecasted a $32.8 \%$ average decline over the next 10 years. According to these results, the species should be listed as 'Vulnerable' at a national scale (SCTS). At the regional level, the conservation status of the species is of particular concern in Andalusia and Castile-Leon, where the species qualifies for listing as 'Endangered'.

\section{Discussion}


Our results highlight the concerning conservation status of the European Dupont's lark population, undergoing a 3.9\% annual decline rate. Under this scenario, the implementation of a wide-ranging conservation plan is urgently needed and is vital to ensuring the conservation of this steppe-bird species. The role of administrations in matters of nature protection and the cataloguing of endangered species is crucial to reverse declining population trends of this and other endangered taxa. 


\section{European population trends and current conservation status of an}

\section{2 endangered steppe-bird species: the Dupont's lark Chersophilus duponti}

3 Julia Gómez-Catasús ${ }^{1}$; Cristian Pérez-Granados ${ }^{1,2}$; Adrián Barrero ${ }^{1}$; Gerard Bota ${ }^{3}$; David Giralt ${ }^{3}$;

4 Germán M. López-Iborra ${ }^{2}$; David Serrano ${ }^{4}$ Juan Traba ${ }^{1}$

$5 \quad{ }^{1}$ Terrestrial Ecology Group (TEG-UAM), Department of Ecology, Universidad Autónoma de

6 Madrid. C/ Darwin 2, 23049 Madrid, Spain.

$7 \quad{ }^{2}$ Multidisciplinary Institute for Environmental Studies “Ramón Margalef”, Department of

8 Ecology, Universidad de Alicante, PO Box 99, 03080 Alicante, Spain.

$9 \quad{ }^{3}$ Biodiversity and Animal Conservation Lab., Forest Sciences Centre of Catalonia (CTFC). Crta.

10 de Sant Llorenç de Morunys km 2, 25280 Solsona, Catalonia, Spain.

$11{ }^{4}$ Department of Conservation Biology, Estación Biológica de Doñana (EBD-CSIC). Avda

12 Américo Vespucio 26, 41092 Sevilla, Spain.

13 Corresponding Author:

14 Julia Gómez-Catasús ${ }^{1}$

15 E-mail address: julia.gomez@uam.es 


\section{Abstract}

\section{Background}

Steppe-birds face drastic population declines throughout Europe. The Dupont's lark Chersophilus duponti is an endangered steppe-bird species whose European distribution is restricted to Spain. This scarce passerine bird could be considered an 'umbrella species', since its population trends may reveal the conservation status of shrub-steppes. However, trends for the Spanish, and thus European, population of Dupont's lark are unknown.

In this work, we evaluated Dupont's lark population trends in Europe employing the most recent and largest compiled database to date (92 populations over 12 years). In addition, we assessed the species threat category according to current applicable criteria (approved in March 2017) in the Spanish Catalogue of Threatened Species (SCTS), which have never been applied to the Dupont's lark nor to any other Spanish species. Finally, we compared the resulting threat categories with the current conservation status at European, national and regional levels.

\section{Methods}

We fitted Switching Linear Trend models (software TRIM - Trends and Indices for Monitoring data) to evaluate population trends at national and regional scale (i.e. per Autonomous

Community) during the period $2004-2015$. In addition, the average finite annual rate of change

$(\bar{\lambda})$ obtained from the TRIM analysis was employed to estimate the percentage of population size change in a 10-year period. A threat category was assigned following A1 and A2 criteria applicable in the SCTS. $\lambda$

\section{Results}

Trends showed an overall 3.9\% annual decline rate for the Spanish population (moderate decline, following TRIM). Regional analyses showed high inter-regional variability. We forecasted a 
$4032.8 \%$ average decline over the next 10 years. According to these results, the species should be

41 listed as 'Vulnerable' at a national scale (SCTS). At the regional level, the conservation status of

42 the species is of particular concern in Andalusia and Castile-Leon, where the species qualifies for

43 listing as 'Endangered'.

44 Discussion

45 Our results highlight the concerning conservation status of the European Dupont's lark

46 population, undergoing a 3.9\% annual decline rate. Under this scenario, the implementation of a

47 wide-ranging conservation plan is urgently needed and is vital to ensuring the conservation of

48 this steppe-bird species. The role of administrations in matters of nature protection and the

49 cataloguing of endangered species is crucial to reverse declining population trends of this and

50 other endangered taxa.

\section{Introduction}

52 Steppes and pseudo-steppes are two of the most important habitats for the preservation of bird diversity, since 55\% of European bird species listed on the IUCN Red List are highly dependent on these habitats (Burfield 2005). Moreover, 83\% of steppe-bird species show an unfavorable conservation status in Europe (Burfield and Van Bommel 2004, Burfield 2005). This is a consequence of the accelerated process of land use changes occurring in steppe-like habitats, with dramatic consequences for steppe-bird populations across Europe (Benton et al. 2003, Burfield and Van Bommel 2004, Santos and Suárez 2005). The main habitat-related threats, and therefore drivers of steppe-bird population declines are: (i) changes in land use (afforestation, new crops, infrastructure development, mining, rubbish dumps; Burfield 2005; Laiolo and Tella

61 2006a, Gómez-Catasús et al. 2016, 2018); (ii) agricultural intensification (landscape

62 homogenization, irrigation, increase in the use of agrochemicals; Donald et al. 2001, Benton et 
63 al. 2003, Brotons et al. 2004, Burfield 2005); and (iii) land abandonment and changes in

64 agriculture and livestock management (Madroño et al. 2004, Burfield 2005).

65 Spain is the stronghold for steppe-birds in Western Europe, harbouring a large proportion of their

66 total European breeding population (Burfield 2005). However, most of the Spanish steppe-bird

67 populations declined during the 1990 - 2000 period (Burfield 2005) and later (BirdLife

68 International 2015). A species of particular conservation concern is the Dupont's lark

69 Chersophilus duponti (Vieillot, 1820), identified amongst the 65 priority bird species inhabiting

70 steppes (Burfield and Van Bommel 2004) and one of the scarcest passerine birds with a rather

71 restricted distribution range in Europe. The species is classified as 'Near Threatened' on the

72 IUCN Red List (BirdLife International 2017) and as 'Vulnerable' on both the European Red List

73 of Birds (BirdLife International 2015) and on the Spanish Catalogue of Threatened Species

74 (Royal Decree 139/2011, $4^{\text {th }}$ February). Its European geographic range is restricted to Spain

75 spreading over $1,480 \mathrm{~km}^{2}$ (Suárez 2010), and its population has been estimated at 1,300-2,400

76 breeding pairs (Garza et al. 2003, Tella et al. 2005, Suárez 2010). The European population of

77 Dupont's lark qualifies for consideration as an Evolutionary Significant Unit (sensu Moritz 1994,

78 Casacci et al. 2014), as they are isolated and genetically and morphologically differentiated from

79 the African populations (García et al. 2008, Suárez 2010).

80 The species inhabits flat $(<10-15 \%$ of slope) shrub-steppes, avoiding dry pastures and cereal

81 fields (Garza et al. 2005, Seoane et al. 2006, Pérez-Granados et al. 2017). Habitat fragmentation

82 and land use changes, common issues in steppe ecosystems, have been documented as the main

83 threats to the species (Tella et al. 2005, Íñigo et al. 2008, Garza and Traba 2016, Pérez-Granados

84 et al. 2016, Gómez-Catasús et al. 2018). 
85 European Dupont's lark population trends have been previously assessed globally (Suárez 2010)

86 or in a sample of populations (Tella et al. 2005, Pérez-Granados and López-Iborra 2013, 2014).

87 Despite the fact that the results of all of these studies showed declining population trends, none

88 of them derived population change estimates using appropriate statistical methods. Moreover,

89

90

91

92 current trends for the whole Spanish (and European) population are unknown, so an updated and rigorous assessment is needed. This updated information would allow an assessment of the conservation status of the species based on a formal set of criteria at two spatial scales: national and regional (i.e., per Autonomous Community where the species is present). The importance of both spatial scales relies on the jurisdiction of the Spanish Autonomous Communities in nature protection and, specifically, in listing and cataloguing endangered species (Law 42/2007, 13 ${ }^{\text {th }}$ December). The Spanish Ministry of Agriculture and Fisheries, Food and Environment has the jurisdiction to list the species at a national scale in the Spanish Catalogue of Threatened Species (SCTS, Law 42/2007, $13^{\text {th }}$ December) and to elaborate the National Conservation Strategy of endangered species. On the other hand, each Autonomous Community is legally bound to list species in its Regional Catalogue of Threatened Species (RCTS), at least with the same category as at the national level. In addition to this, they have the competence to elaborate and implement both Conservation and Recovery Plans for those species classified as 'Vulnerable' and 'Endangered', respectively. Thus, regional population trends are crucial to assess whether species conservation status is of particular concern in specific regions and if the category of threat should be increased in the pertinent Catalogues.

The species included in the SCTS were listed in 2011 (Royal Decree 139/2011), but listing criteria applicable in the SCTS were modified in March 2017 (Royal Decree 139/2011, $4^{\text {th }}$ February; Resolution 6th March 2017), to accommodate those of the IUCN (IUCN 2012). 
108 However, the conservation status of catalogued species in the SCTS has not been reviewed since 109 this modification. To our knowledge, new criteria have never been applied to the Dupont's lark

110 nor to any other Spanish species and, therefore, an assessment of the category of threat assigned

111 under the new criteria is needed.

112 In this work, we aimed to evaluate Dupont's lark population trends during the $2004-2015$ period

113 at both national and regional scales, using the largest database ever compiled. We also carried

114 out a comprehensive assessment of the conservation status of the Dupont's lark according to 115 quantitative threshold criteria of reduction in population size (A1 and A2 criteria, see below) 116 under the SCTS (Resolution 6th March 2017). Finally, we aimed to assess whether the current

117 threat category of the species at European (European Red List of Birds), national (SCTS) and 118 regional levels (RCTS) agrees with Dupont's lark populations trends.

\section{Materials and Methods}

120

121

122

123

124

125

126

127

128

129

\section{Data collection}

The ethics committee of Animal Experimentation of the Autonomous University of Madrid as an Organ Enabled by the Community of Madrid (Resolution 24th September 2013) for the evaluation of projects based on the provisions of Royal Decree 53/2013, 1st February, has provided full approval for this purely observational research (CEI 80-1468-A229).

We compiled data for 92 Dupont's lark populations during the 2004 - 2015 period. This dataset comprised $41.6 \%$ of the known Spanish population (221 populations surveyed during the II National Survey 2004-2006; Suárez 2010) and included all of the Autonomous communities where the species occurs (Fig. 1) (Suárez 2010). The time series addresses a temporal range between one and 12 years (mean $\pm \mathrm{SD}=5.36 \pm 2.77$ years). We considered a single population 
130 to be all individuals living in patches with potential habitat for the species (i.e., short shrub with

131 slopes lower than 15\%; Garza et al. 2005) separated by less than $1 \mathrm{~km}$.

132 The Dupont's lark population size is difficult to quantify due to the extremely shy and elusive

133 behavior of the species and the concentration of singing activity mainly before dawn. Therefore,

134 surveys of the species rely on auditory contacts. Bird censuses were carried out during the

135 breeding season (March-June depending on phenological differences; Garza et al. 2010)

136 approximately 1 hour before dawn, when singing activity peaks, and they spanned around 1

137 hour. Birds were counted by linear transects (500 m inner belt width; Garza et al. 2010) or by

138 territory mapping (Bibby et al. 2000), with the two methods producing similar population size

139 estimates (Pérez-Granados and López-Iborra 2017). A slightly different census method,

140 consisting of a network of point counts, was performed in Catalonia and Region of Murcia

141 populations (comprising less than $5 \%$ of all populations). Counting method remained constant

142 throughout the study period within each region, making inter-annual data comparable. Linear

143 transects were designed to cover the whole population (Suárez 2010), and were walked at a

144 constant speed, georeferencing singing males with a GPS and noting all males singing

145 simultaneously. Transects were walked once per year under the linear transect method and 2-4

146 times per year under the mapping method. In the case of the territory mapping method, number

147 of territories per population was estimated by mapping all records and gathering accumulated

148 observations from different surveys, taking into account birds heard simultaneously (Garza et al.

149 2010, Pérez-Granados and López-Iborra 2017). Population size estimates refer to the minimum

150 number of territories (mapping method), or minimum number of recorded males (line transect

151 method) per population. Lastly, we considered a population as extinct when the species was not

152 detected in at least the last two surveys (hereafter local extinction event). 


\section{Trend analysis}

154 Changes in population estimates were evaluated using the software TRIM (Trends and Indices

155 for Monitoring data. TRIM v. 3.54. Pannekoek and Van Strien 2006a). TRIM fits log-linear

156 models and was employed because: i) it allows the analysis of time series with the absence of

157 data for some years, a common issue in long-term time series; and ii) it takes into account

158 overdispersion and serial correlation of data (Pannekoek and Van Strien 2005). TRIM calculates

159 indices that represent the effect of change between years, which indicates relative variation of the

160 total population size. Two types of indices are estimated: i) model-based indices, which are the

161 values predicted by the model; and ii) imputed indices, which equal the observed count if an

162 observation is made and the model prediction for missing counts (Pannekoek and Van Strien

163 2005). Dissimilarity between the two indices reflects a mismatch between observed (i.e. imputed

164 indices) and model predictions (i.e. model-based indices) and, therefore, a lack of fit of the

165 statistical model applied. Imputed indices are employed to estimate a mean annual change rate

166 since they show a more realistic course in time (Pannekoek and Van Strien 2006b) and a trend

167 category is assigned (Pannekoek and Van Strien 2006a). At the first time-point, the index value

168 is 1 and is taken as a reference point for quantifying the relative temporal trends in the

169 subsequent years. This technique has been broadly employed for the analysis of temporal series

170 in bird populations (e.g. Paradis et al. 2002, Wretenberg et al. 2007, Delgado et al. 2009,

171 Gómez-Catasús et al. 2018).

172 We fitted Switching Linear Trend models to evaluate both national and regional Dupont's lark

173 trends during the period 2004 - 2015. TRIM employs a stepwise selection of change-points in

174 trends using Wald-tests for the significance of change-points. When the difference between

175 parameters before and after a change-point does not differ from zero (default significance 
176 threshold: 0.2 ), the corresponding change-point is removed from the model complying with the

177 parsimony principle (Pannekoek and Van Strien 2005). The best-fit models were selected

178 according to Goodness-of-fit tests (Likelihood ratio test and Chi-squared) and Akaike

179 information criterion (AIC). A model with a significance value greater than 0.05 indicates that

180 the data fit a Poisson distribution and, therefore, the model can be accepted. Indices, overall

181 slope and Wald tests remain reliable in case of lack-of-fit (Pannekoek and Van Strien 2005). In

182 case of overdispersion or serial correlation (default TRIM threshold: $>3.0$ and $>0.4$ respectively;

183 Pannekoek and Van Strien 2006b), the Wald-test for the significance of slope was employed

184 (Pannekoek and Van Strien 2005). While the whole set of 92 populations was used to analyse

185 national trends, regional subsets were subsequently extracted to analyse regional trends (see

186 Table 1 for sample size in each region).

187 Threat category

188 We evaluated the Dupont's lark category of threat according to A1 (population size reduction 189 over the last 10 years or three generations, whichever is longer) and A2 (population size 190 reduction within the next 10 years or three generations, whichever is longer) criteria applicable 191 in the SCTS. We employed a 10 year period because it is longer than 3 generations (generation

192 length of the Dupont's lark is estimated at 2.5 years; Íñigo et al. 2008). We used recent trends to 193 forecast future population trends of the species, since its geographic range reduction (Traba et al. 194 2016) and the lack of conservation measures (Tella et al. 2005, Suárez 2010, Pérez-Granados 195 and López-Iborra 2014) predict similar population trends in the following years.

196 The average finite annual rate of change $(\bar{\lambda})$ during the study period was obtained from the 197 TRIM analysis. This is a multiplicative factor representing the average growth rate over one 198 time-step (i.e., one year). When this multiplicative factor is $\bar{\lambda}<1$ the population decreases; when 
$199 \bar{\lambda}=1$ the population remains stable; and when $\bar{\lambda}>1$ the population increases. The $\bar{\lambda}$ value was

200 employed to estimate the percentage of population size change in a 10-year period following the

201 equation below:

202

Percentage of change in a 10 -year period $(\%)=\left(\bar{\lambda}^{10}-1\right) \cdot 100$

203 We assigned a threat category according to population size reduction estimated over the last 10

204 years (A1 criterion; 'Endangered' $\geq 70 \%$ 'Vulnerable' $\geq 50 \%$ ) and forecasted in the next 10

205 years (A2 criterion; 'Endangered' $\geq 50 \%$ 'Vulnerable' $\geq 30 \%$ ) at both national and regional

206 scales. Lastly, categories were compared with the current threat categories for the Dupont's lark

207 on the European Red List of Birds, the SCTS and the RCTS.

\section{Results}

209 Spanish (European) population trend

210 The best Switching Linear Trend model for all Dupont's lark populations did not fit a log-linear

211 distribution (Chi-square, $\chi^{2}=684.92, \mathrm{df}=389, \mathrm{p}<0.001$; Likelihood Ratio, $\mathrm{LR}=722.30, \mathrm{df}=$

$212389, \mathrm{p}<0.001 ; \mathrm{AIC}=-55.70)$. Overdispersion and serial correlation values were relatively low

213 (1.70 and 0.34 , respectively), but $55.8 \%$ of counts were missing values. The stepwise procedure

214 revealed six significant change-points in trends (Fig. 2; Table S1). The population size index

215 experienced an overall 41.4\% decline (95\% CI, -50.5 to -32.4) from 2004 to 2015. Furthermore,

216 the extinction of 20 populations, which represents $21.7 \%$ of the set of study populations, was

217 registered in this period (Table S2). The overall slope parameter showed a 3.9\% annual decrease

$218(95 \% \mathrm{CI},-4.9$ to $-2.8 \%)$, which corresponds to a moderate decline according to TRIM criteria

219 (Pannekoek and Van Strien 2006a). 
221 Regional trends showed high variability between regions (Table 1; Fig. 3). Switching Linear

222 Trend models for Aragon (AR), Navarre (NA) and Region of Murcia (RM) populations fitted a

223 log-linear distribution $\left(\chi^{2}\right.$ and LR p-values $\left.>0.05\right)$, while Goodness-of-fit tests for models of

224 Andalusia (AN) and Community of Valencia (CV) were near acceptance values ( $\chi^{2}$ and LR p-

225 values > 0.01; Table 1). However, Castile-La Mancha (CM) and Castile-Leon (CL) models did

226 not fit a log-linear distribution $\left(\chi^{2}\right.$ and LR p-values $<0.01$; Table 1). Overdispersion and serial

227 correlation values were of less concern for all models except for Catalonia (CA; Table 1), so we

228 relied on Wald-tests for best-model selection. The proportion of missing values was higher than

$22950 \%$ for AR, CM, CA and NA models, and sample sizes were small for all regions (i.e., less than

23015 populations) except for CM and CL (Table 1). Significant change-points in slope were

231 incorporated in all models except for AR, CA and NA (Fig. 3; Table S3), due to a constant slope

232 in trends throughout the study period (AR and NA) or to sparse data that hindered the fitting of a

233 Switching Linear Trend model (CA). Trend analyses showed mean overall decreases in AN

234 (66.8\%), CM (59.0\%), CL (51.1\%), CA (42.9\%), CV (30.1\%) and NA (11.0\%) during the 2004

$235-2015$ period (Table 2). However, mean overall trends were positive in AR (18.7\%) and RM

$236(55.2 \%)$ populations (Table 2). Average annual change rates showed a steep decline for AN and

237 CL populations, greater than 5\% per year (Table 1; Fig. 3). Population trends of AR, CA, CM,

$238 \mathrm{CV}$, NA and RM were classified as uncertain (Table 1). Local extinction events were registered

239 mainly in AN (6), CL (5) and CM (5) (Table S2). The only population in CA (Alfés) and one

240 population in AN (Sierra de Gador-Llano de los Brincos) experienced a local extinction event

241 followed by a recolonization event. 
243 According to the estimated mean annual rate of change (-3.9\%), the Dupont's lark population

244 size in Spain has been reduced on average by $32.8 \%$ over the last 10 years and we expect it to be

245 reduced by the same percentage in the next 10 years (Table 2). This reduction in population size

246 does not entail the classification of the Dupont's lark at any category of threat in Spain according

247 to A1 criterion (Table 2). However, the Dupont's lark should be classified as 'Vulnerable' on the

248 SCTS according to A2 criterion (Table 2).

249 Regional analyses showed that the species should be classified as 'Vulnerable' in AN and CL

250 according to past population trends (A1 criterion) while no category of threat is assigned in the

251 rest of the Regional Catalogues (Table 2). Nevertheless, the species should be classified at least

252 as 'Vulnerable' in all the Regional Catalogues according to forecasted population declines (A2

253 criterion) and Spanish legislation (Table 2). Specifically, the species should be upgraded to

254 'Endangered' in AN and CL in agreement with A2 criterion (Table 2).

255 Discussion

256 Our results provide evidence of concerning trends for the Spanish Dupont's lark population, the

257 remaining bastion of this endangered steppe-bird in Europe. The species exhibited an estimated

258 annual decline rate of $3.9 \%$ over the last decade and a $41.4 \%$ decline over 12 years (2004-

259 2015). This result agrees with previously described trends for the Dupont's lark (Tella et al.

260 2005, Pérez-Granados and López-Iborra 2013) and for most of steppe-bird species in the Iberian

261 Peninsula (Burfield 2005, BirdLife International 2015). Previous work on Spanish Dupont's lark

262 population trends suggested a $31.5 \%$ decline in 16 years $(\mathrm{N}=34$ populations; Tella et al. 2005)

263 and a $70 \%$ decline in 12.5 years $(\mathrm{N}=33$ populations; Pérez-Granados and López-Iborra 2014).

264 In particular areas of its Spanish distribution, positive trends have been previously estimated in 265 Aragon $(\mathrm{N}=7)$ and Region of Murcia $(\mathrm{N}=2)$, whereas declining population trends have been 
266 described for Andalusia (N=4), Castile-La Mancha (N=6), Castile-Leon (N=6), Community of

267 Valencia $(\mathrm{N}=6)$ and Navarre $(\mathrm{N}=2)$ populations (a decline between $22 \%$ and $98 \%$ in 12.5 years;

268 Pérez-Granados and López-Iborra 2014). The novelty of the present work relies on the

269 employment of a rigorous statistical method and on the incorporation of a greater number of

270 Dupont's lark populations $(\mathrm{N}=92)$ covering a wider range of its European distribution.

271 In this study, we compiled the most updated database for Dupont's lark population trends. We

272 considered that our geographical coverage is representative of the Spanish (European)

273 distribution, leading to reliable results for the population trend analysis. Most regions were

274 significantly represented in this sample, ranging from $43 \%$ of the total regional population for

$275 \mathrm{CL}$, to $48 \%$ for $\mathrm{CM}$ and $100 \%$ for $\mathrm{AN}, \mathrm{CA}, \mathrm{CV}, \mathrm{NA}$ and RM. However, we only were able to

276 compile data on 10 populations for AR (10.5\% of the 95 populations surveyed in 2004-2006;

277 Suárez 2010), the region in which the majority of the Spanish Dupont's lark population is

278 concentrated (Suárez 2010). In addition, and regarding the temporal coverage, a high proportion

279 of counts within specific populations are missing. Thus, overall trends $(3.9 \%$ annual decline rate)

280 may be somewhat biased due to the absence of data throughout the years and for important

281 populations. Therefore, future population trend analyses incorporating a higher proportion of the

282 regional populations in $\mathrm{AR}$ are needed, as well as more intensive monitoring to avoid missing

283 temporal data. Accordingly, priority should be given to standardizing and coordinating among

284 populations long-term monitoring, particularly in those large populations in Aragon.

285 One additional precaution is related to the lack of fit in models, probably due to missing counts

286 and slight overdispersion in data (i.e. variance greater than the mean). A higher proportion of

287 missing counts leads to greater uncertainty, relying on the statistical model to estimate missing

288 counts. This uncertainty hampers model fitting and may produce population indices that reflect 
289 changes in the pattern of missing values rather than real trends (e.g. CA; Pannekoek and Van

290 Strien 2005). On the other hand, overdispersion could be due to unknown variables not

291 incorporated in the models, which could influence trends (Quinn and Keough 2002, Crawley

292 2007). For instance, interannual variability in population trends encompassed by the significant

293 change-points (Table S1; Table S3) could be explained by natural stochasticity, either

294 demographic or environmental (Lande 1987), as well as density-dependent interactions

295 (Bjørnstad and Grenfell 2001). Demographic stochasticity, especially in small and isolated

296 populations, may be an important driver of the observed oscillations between years, since

297 Dupont's lark seems to fit to a metapopulation structure with local extinction events and

298 colonization processes (e.g. Alfés population in CA; Bota et al. 2016). This produces high

299 variability in TRIM yearly indices (i.e. overdispersion), and therefore hinders the estimation of

300 generalized population trends over time. On the other hand, interannual variability may also be

301 associated with environmental stochasticity and fluctuations in abiotic factors, such as climate

302 (Delgado et al. 2009) due to its effects on food availability (Wiens 1989, Lemoine et al. 2007),

303 reproductive success (Bolger et al. 2005, Van de Pol et al. 2010) or annual survival (Robinson et 304 al. 2007), among others. Future research should focus on disentangling the mechanisms

305 underlying variability in trends in order to incorporate new covariates in models and improve

306 their Goodness-of-fit. Regardless, the lack of fit would not invalidate indices, overall slope or

307 Wald tests (Pannekoek and Van Strien 2005), and consequently the main results regarding

308 Dupont's lark population trends remain reliable.

309 We found large differences between regions in population trends; drastic declining trends

310 (annual declining rate higher than 5\%) occurred in AN and CL, while trends were classified as

311 uncertain in the other regions (AR, CM, CA, CV, NA and RM). Uncertainty in trends may be 
312 due to two typical handicaps in long-term databases: (i) high variability between years and

313 populations (within a region) that produces large Confidence Intervals (i.e., overdispersion); and

314 (ii) high proportion of missing values (Atkinson et al. 2006). As stated above, overdispersion

315 was low except in CA, which could be explained by the extinction-recolonization process

316 undergone by the single population in this region (Bota et al. 2016). The percentage of missing

317 values (Table 1) exceeded the recommended threshold of 20-50\% for TRIM analyses

318 (Pannekoek and Van Strien 2005). These two analytical constraints have negligible effects at the

319 national scale but less reliable estimates are expected to be obtained with small-size samples

320 (i.e., regional analysis; Atkinson et al. 2006). The most remarkable case is for the population of

321 CA, where overdispersion, small sample size and a high percentage of missing values prevent the

322 fitting of a Switching Linear Trend model and lead to a mismatch between model-based (i.e.,

323 model predictions) and imputed (i.e., observed counts) indices (Fig. 3). Consequently, results for

324 some regional trends should be treated with caution, especially when dealing with a low

325 proportion of populations (i.e. low geographical coverage, e.g. AR; see above) and/or high

326 percentage of missing values (i.e. low temporal coverage).

327 Inter-region variability in trends may be due to spatial variation in factors threatening Dupont's

328 lark populations. Declining population trends in AN may be due to agro-forestry (Laiolo and

329 Tella 2006a) and irrigated land expansion (Íñigo et al. 2008) which have taken place over the last

330 decade. In addition, isolation and small population size make the AN populations more prone to

331 extinction (Méndez et al. 2011). On the other hand, declining trends for the CL populations can

332 be mainly explained by the implementation of wind farm infrastructures (Gómez-Catasús et al.

333 2018) or high-speed trains (Íñigo et al. 2008), as well as conifer plantations promoted by the

334 Common Agricultural Policy over marginal low-productivity areas (Tella et al. 2005, Garza and 
335 Traba 2016). The uncertainty in population trends for the other regions makes it difficult to find

336 a potential explanation, although agro-forestry (RM; Laiolo and Tella 2006a), irrigated lands

337 (AR; Íñigo et al. 2008), afforestations (AR, CV, NA, RM; Tella et al. 2005, Garza and Traba

338 2016) and infrastructure development (highways in AR; Íñigo et al. 2008, Garza and Traba

339 2016) are among the probable causes. In addition, demographic stochasticity may be a crucial

340 driver of population trend oscillations in small and isolated populations such as AN, CA, NA and

341 RM. In any case, agricultural intensification and abandonment of traditional extensive livestock

342 are general processes known to impact shrub-steppes (Santos and Suárez 2005), and particularly

343 Dupont's lark populations (Tella et al. 2005, Íñigo et al. 2008, Garza and Traba 2016, Gómez-

344 Catasús et al. 2016).

345 The comprehensive assessment of the conservation status of the Dupont's lark yielded a higher

346 category of threat according to A2 criterion (future population trends) than A1 criterion (past

347 population trends). The fulfillment of one criterion is enough to classify the species at the highest

348 category of threat. Thus, according to A2 criterion, the Dupont's lark is correctly listed as

349 'Vulnerable' on the European Red List of Birds, on the SCTS and on the Regional Catalogues of

$350 \mathrm{CM}, \mathrm{CV}$ and RM. Of particular concern, however, are Dupont's lark populations in AN and CL,

351 where the species qualifies for listing as 'Endangered'. However, CL has not yet elaborated a

352 RCTS, while the species is currently listed as 'Vulnerable' in AN. In the other regions (AR, CA

353 and NA), the species should be classified as 'Vulnerable' according to the category of threat

354 assigned in the SCTS (Law 42/2007, $13^{\text {th }}$ December). If the same assessment had been carried

355 out using previous applicable criteria in the SCTS (before March 2017; Dirección General para

356 la Conservación de la Naturaleza 2004), the cataloguing scenario would have changed

357 drastically. Under the old criteria, the Dupont's lark should have been listed as 'Endangered' (A2 
358 criterion; population size reduction of $\geq 40 \%$ within the next 20 years), providing evidence of the

359 effects that listing criteria modification may have on the management and conservation of

360 threatened species.

361 In this study, we assessed the conservation status of the European Dupont's lark population

362 according to A criteria, since we had no reliable data for including other criteria in our analyses.

363 Therefore, a similar comprehensive assessment should be carried out considering the remaining

364 listing SCTS criteria (reduction in area of occupancy and/or population viability analysis;

365 Resolution $6^{\text {th }}$ March 2017) to elucidate whether or not the species should be classified as

366 'Endangered', ensuring proper listing of the species at both European and national levels. For

367 instance, there is consensus among experts (D criteria; Resolution $6^{\text {th }}$ March 2017) about the

368 need for its reclassification as "Endangered" (Tella et al. 2005, Pérez-Granados and López-

369 Iborra 2014, Garza and Traba 2016). Future research should focus on accurately estimating the

370 reduction in area of occupancy. Moreover, a demographic population viability analysis assessing

371 the extinction risk in the coming years should be carried out, although estimating reliable

372 demographic parameters for the whole population of this secretive species is challenging.

373 Conclusions

374 Despite methodological constraints due to slight overdispersion, missing data, and a low

375 proportion of populations incorporated for AR, we believe that our results in relation to the

376 conservation status of the species in Europe are conclusive. The European Dupont's lark

377 population faces a $3.9 \%$ annual decline rate, entailing an expected average population decline of

$37832.8 \%$ within the next 10 years. The pressures faced by the species have not ceased in recent

379 years (Tella et al. 2005, Íñigo et al. 2008, Garza and Traba 2016), and may be expected to

380 increase in the future due to strong fragmentation and high vulnerability to stochastic factors 
381 (Laiolo and Tella 2006b, Vögeli et al. 2010, Méndez et al. 2011). Under this scenario, the

382 implementation of a wide-range conservation plan for the Iberian distribution is vital to ensure

383 the conservation of the species (Íñigo et al. 2008). According to Spanish legislation, the

384 elaboration of a Conservation Plan is mandatory for those species classified as 'Vulnerable',

385 such as the Dupont's lark since 2004 (Orden MAM/2784/2004), and this is within the

386 jurisdiction of the Autonomous Communities. In addition, Autonomous Communities are legally

387 obligated to comply with current legislation in cataloguing endangered species (Law 42/2007,

$38813^{\text {th }}$ December). Therefore, the species should be classified as 'Endangered' in Andalusia and

389 Castile-Leon, and as 'Vulnerable' in Aragon, Catalonia and Navarra. In this context, the legal

390 responsibility of administrations is crucial to reverse declining population trends of this and other

391 endangered taxa.

\section{Acknowledgements}

393

394

395

396

397

398

399

400

401

402

403

404

405

406

407

The authors wish to thank all the people that disinterestedly provided their data on Dupont's lark populations in Spain.

\section{References}

Atkinson, P. W., Austin, G. E., Rehfisch, M. M., Baker, H., Cranswick, P., Kershaw, M., Robinson, J., Lagnston, R. H. W., Stroud, D. A., Van Turnhout, C. and Maclean, I. M. (2006). Identifying declines in waterbirds: The effects of missing data, population variability and count period on the interpretation of long-term survey data. Biological Conservation, 130: 549-559.

Benton, T. G., Vickery, J. A. and Wilson, J. D. (2003). Farmland biodiversity: is habitat heterogeneity the key? Trends of Ecology and Evolution, 18: 182-188.

Bibby, C. J., Burgess, N. D., Hill, D. A. and Mustoe, S. (2000). Bird census techniques. London, U.K.: Academic Press.

BirdLife International. (2015). European Red List of Birds. Luxembourg: Office for Official Publications of the European Communitties.

BirdLife International. (2017). Chersophilus duponti. The IUCN Red List of Threatened Species. 
Available at: http://dx.doi.org/10.2305/IUCN.UK.2017-1.RLTS.T22717380A111109346.en (Accesed 1 July 2017).

Bjørnstad, O.N. and Grenfell, B.T. (2001). Noisy clockwork: time series analysis of population fluctuations in animals. Science, 293: 638-643.

Bolger, D. T., Patten, M. A. and Bostock, D. C. (2005). Avian reproductive failure in response to an extreme climatic event. Oecologia, 142: 398-406.

Bota, D., Giralt, D. and Guixé, D. (2016). La alondra ricotí en Cataluña: evolución histórica de una población en el límite del área de distribución. II Workshop Grupo de Expertos en la Alondra ricotí. UAM-Madrid.

Brotons, L., Mañosa, S. and Estrada, J. (2004). Modelling the effects of irrigation schemes on the distribution of steppe birds in Mediterranean farmland. Biodiversity and Conservation, 13: 1039-1058.

Burfield, I. J. (2005). The conservation status of steppic birds in Europe. In G. Bota, M. B. Morales, S. Mañosa, and J. Camprodon (Eds.), Ecology and conservation of steppe-land birds (pp. 69-102). Lynx Edicions, Barcelona, Spain.

Burfield, I. and Van Bommel, F. (2004). Birds in Europe: population estimates, trends and conservation status. BirdLife International. Cambridge, UK.

Casacci, L. P., Barbero, F. and Balletto, E. (2014). The "Evolutionarily Significant Unit" concept and its applicability in biological conservation. Italian Journal of Zoology, 81: 182-193.

Crawley, M. J. (2007). The R Book. John Wiley \& Sons, Hoboken, New Jersey, USA.

Delgado, M. P., Morales, M. B., Traba, J. and De la Morena, E. L. G. (2009). Determining the effects of habitat management and climate on the population trends of a declining steppe bird. Ibis, 151: 440-451.

Dirección General para la Conservación de la Naturaleza. (2004). Criterios orientadores para la inclusión de taxones y poblaciones en catálogos de especies amenazadas. Ministerio de Medio Ambiente, Madrid, Spain.

Donald, P. F., Green, R. E. and Heath, M. F. (2001). Agricultural intensification and the collapse of Europe's farmland bird populations. Proceedings of the Royal Society of London B, 268: $25-29$.

García, J. T., Suárez, F., Garza, V., Calero-Riestra, M., Hernández, J. and Pérez-Tris, J. (2008). Genetic and phenotypic variation among geographically isolated populations of the globally threatened Dupont's lark Chersophilus duponti. Molecular phylogenetics and evolution, 46: 237-251.

Garza, V., Suárez, F. and Carriles, E. (2010). El censo actual: diseño y métodos de muestreo y estima de las poblaciones. In F. Suárez (Ed.), La alondra ricotí (Chersophilus duponti) (pp. 175-194). Dirección General para la Biodiversidad, Ministerio de Medio Ambiente y Medio Rural y Marino, Madrid, Spain. 
Garza, V., Suárez, F., Herranz, J., Traba, J., De la Morena, E. L. G., Morales, M. B., González, R. and Castañeda, M. (2005). Home range, territoriality and habitat selection by the Dupont's lark Chersophilus duponti during the breeding and postbreeding periods. Ardeola, 52: $133-146$.

Garza, V. and Traba, J. (2016). Retos para la conservación de una especia amenazada. Alondra ricotí, el fantasma del páramo. Quercus, 359: 24-33.

Garza, V., Traba, J. and Suárez, F. (2003). Is the European population of Dupont's Lark Chersophilus duponti adequately estimated? Bird Study, 50: 309-311.

Gómez-Catasús, J., Barrero, A., Garza, V. and Traba, J. (2016) Alondra ricotí - Chersophilus duponti. In A. Salvador and M.B. Morales (eds.), Enciclopedia virtual de vetebrados Españoles. Madrid: Museo Nacional de Ciencias Naturales. Retrieved from: http:// www.vertebradosibericos.org

Gómez-Catasús, J. Garza, V. and Traba, J. (2018) Wind farms affect the occurrence, abundance and population trends of small passerine birds: The case of the Dupont's lark. Journal of Applied Ecology. DOI: 10.1111/1365-2664.13107

Íñigo, A., Garza, V., Tella, J. L., Laiolo, P., Suárez, F. and Barov, B. (2008). Action Plan for the Dupont's Lark Chersophilus duponti in the European Union. Madrid, Spain.

IUCN. (2012). IUCN Red List Categories and Criteria: Version 3.1. Second edition. IUCN, Gland, Switzerland and Cambridge, UK.

Laiolo, P. and Tella, J. L. (2006a). Fate of unproductive and unattractive habitats: recent changes in Iberian steppes and their effects on endangered avifauna. Environmental Conservation, 33: $223-232$.

Laiolo, P. and Tella, J. L. (2006b). Landscape bioacoustics allows detection of the effects of habitat patchiness on population structure. Ecology, 87: 1203-1214.

Lande, R. (1987). Extinction thresholds in demofraphic models of territorial populations. The American Naturalist, 130: 624-635.

Lemoine, N., Bauer, H.G., Peintinger, M. and Böhning-Gaese, K. (2007). Effects of climate and land-use changes on species abundance in a central European bird community. Conservation Biology, 21: 495-503.

Madroño, A., González, C. and Atienza, J. C. (2004). Libro rojo de las aves de España. Dirección General para la Biodiversidad- SEO/Birdlife, Madrid, Spain.

Méndez, M., Tella, J. L. and Godoy, J. A. (2011). Restricted gene flow and genetic drift in recently fragmented populations of an endangered steppe bird. Biological Conservation, 144: 2615-2622.

Moritz, C. (1994). Defining "Evolutionarily Significant Units" for conservation. Trends in Ecology and Evolution, 9: 373-375. 
481

482

483

484

485

486

487

488

489

490

491

492

493

494

495

496

497

498

499

500

501

502

503

504

505

506

507

508

509

510

511

512

513

514

515

516

517

Pannekoek, J. and Van Strien, A. (2005). TRIM 3 Manual (Trends and Indices for Monitoring data). Statistics Netherlands, Voorburg, Holland.

Pannekoek, J. and Van Strien, A. (2006a). TRIM version 3.54 (Trends \& Indices for Monitoring data). Statistics Netherlands, Voorburg, Holland.

Pannekoek, J. and Van Strien, A. (2006b). Frequently Asked Questions Updated 2006 (TRIM version 3.51). Statistics Netherlands, Voorburg, Holland. Available at: http://www.birdresearch.jp/1_shiryo/trim/Q\&A_ENG.pdf (Accesed 1 July 2017).

Paradis, E., Baillie, S. R., Sutherland, W. J. and Gregory, R. D. (2002). Exploring densitydependent relationships in demographic parameters in population of birds at a large spatial scale. Oikos, 97: 293-307.

Pérez-Granados, C. and López-Iborra, G. M. (2013). Census of Breeding Birds and Population Trends of the Dupont's Lark Chersophilus duponti in Eastern Spain. Ardeola, 60: 143-150.

Pérez-Granados, C. and López-Iborra, G. M. (2014). ¿Por qué la alondra ricotí debe catalogarse como "En peligro de extinción"? Quercus, 337: 18-25.

Pérez-Granados, C. and López-Iborra, G. M. (2017). Assesment of Counting Methods Used for Estimating the Number of Territorial Males in the Endangered Dupont's Lark. Ardeola, 64: $5-14$.

Pérez-Granados, C., Osiejuk, T., and López-Iborra, G. M. (2016). Habitat fragmentation effects and variations in repertoire size and degree of song sharing among close Dupont's Lark Chersophilus duponti populations. Journal of Ornithology, 157: 471-482.

Pérez-Granados, C., Lopez-Iborra, G. M., and Seoane, J. (2017). A multi-scale analysis of habitat selection in peripheral populations of the endangered Dupont's Lark Chersophilus duponti. Bird Conservation International, 27: 398-413.

Quinn, G. P. and Keough, M. J. (2002). Experimental dessign and data annalysis for biologists. Cambridge University Press, Cambridge, UK.

Robinson, R. A., Baillie, S. R. and Crick, H. Q. (2007). Weather-dependent survival: implications of climate change for passerine population processes. Ibis, 149: 357-364.

Santos, T. and Suárez, F. (2005). Biogeography and population trends of iberian steppe bird. In G. Bota, M. B. Morales, S. Mañosa, and J. Camprodon (Eds.), Ecology and conservation of steppe-land birds (pp. 69-102). Lynx Edicions, Barcelona, Spain.

Seoane, J., Justribo, J. H., García, F., Retamar, J., Rabadan, C. and Atienza, J. C. (2006). Habitat-suitability modelling to assess the effects of land-use changes on Dupont's lark Chersophilus duponti: a case study in the Layna Important Bird Area. Biological Conservation, 128: 241-252.

Suárez, F. (2010). La alondra ricotí (Chersophilus duponti). Dirección General para la Biodiversidad, Ministerio de Medio Ambiente y Medio Rural y Marino Medio Rural y Marino, Madrid, Spain. 
518 Tella, J. L., Vögeli, M., Serrano, D. Y. and Carrete, M. (2005). Status of the threatened Dupont's 519 lark in Spain: overestimation, decline and extinction of local populations. Oryx, 39: 1-5.

520 Traba. J., Gómez-Catasús, J., García-Antón, A., Barrero, A. and Garza, V. (2016). Bases

521 científicas para la elaboración de la estrategia nacional de conservación de la alondra ricotí.

522 Informe inédito. Fundación Biodiversidad.

523 Van De Pol, M., Ens, B. J., Heg, D., Brouwer, L., Krol, J., Maier, M., Exo, K., Oosterbeek, K., 524 Lok, T., Eising, C. M. and Koffijberg, K. (2010). Do changes in the frequency, magnitude 525 and timing of extreme climatic events threaten the population viability of coastal birds? $526 \quad$ Journal of Applied Ecology, 47: 720-730.

527 Vögeli, M., Serrano, D., Pacios, F. and Tella, J. L. (2010). The relative importance of patch habitat quality and landscape attributes on a declining steppe-bird metapopulation. Biological Conservation, 143: 1057-1067.

Wiens, J.A. (1989). The Ecology of Bird Communities. Vol 2. Processes and Variations. Cambridge University Press, Cambridge, UK.

Wretenberg, J., Lindström, A., Svensson, S. and Pärt, T. (2007). Linking agricultural policies to population trends of Swedish farmland birds in different agricultural regions. Journal of Applied Ecology, 44: 933-941. 


\section{Figure 1 (on next page)}

Dupont's lark distribution in Spain according to Suárez, 2010 (light grey) and Dupont's lark populations included in this study (black).

The names of the Autonomous Communities where the species is present, are shown. The arrow refers to an isolated region belonging to the Community of Valencia. AN: Andalusia. AR: Aragon. CA: Catalonia. CL: Castile-Leon. CM: Castile-La Mancha. CV: Community of Valencia. NA: Navarre. RM: Region of Murcia. 


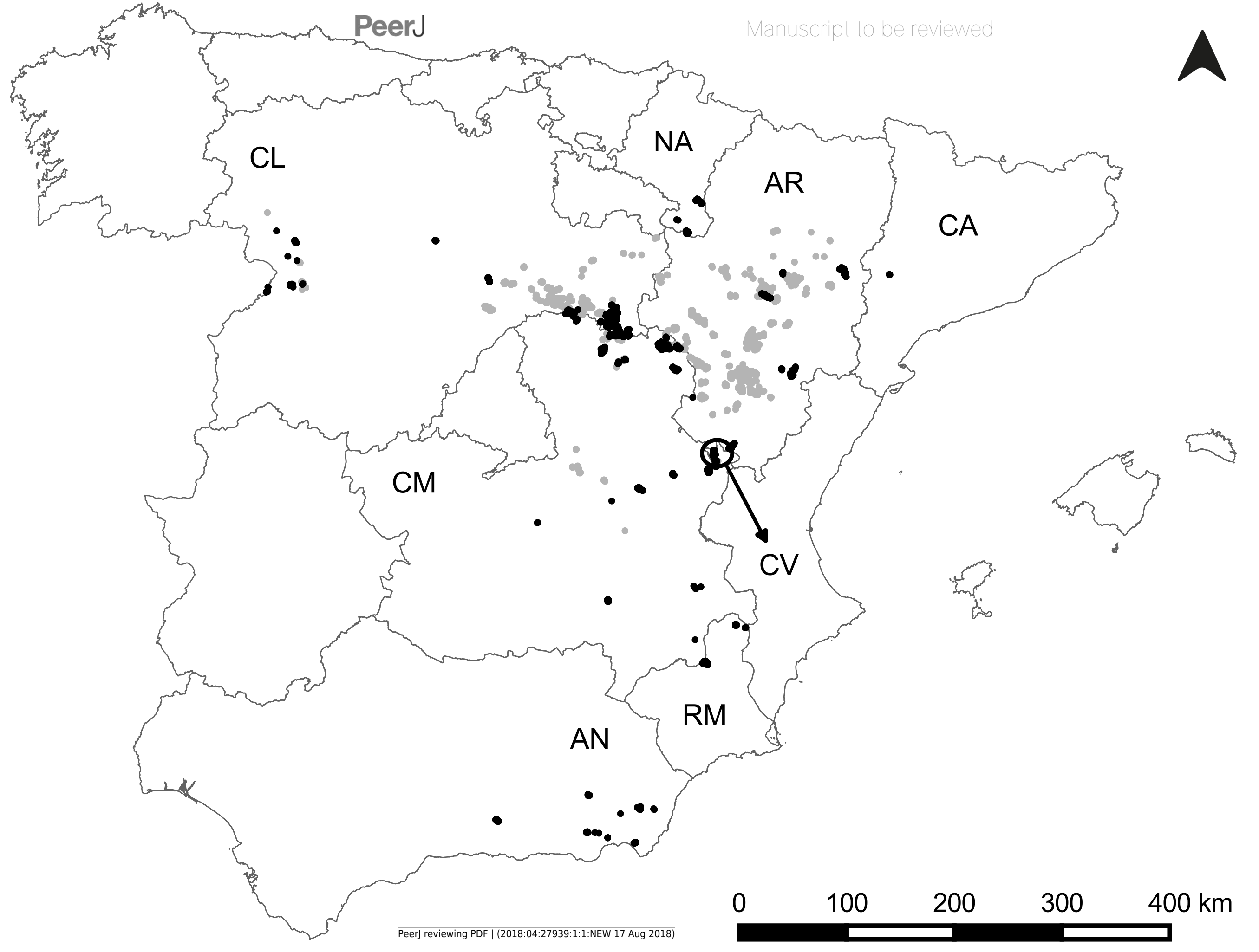


Figure 2

Imputed (grey continuous line) and predicted (black continuous line) population size indices estimated by the Switching Linear Trend model for 92 Dupont's lark populations during the 2004 - 2015 period.

Time-points incorporated in the model as significant change-points on population trends are marked with asterisk (*). 95\% Confidence Intervals (striped grey lines) are depicted.

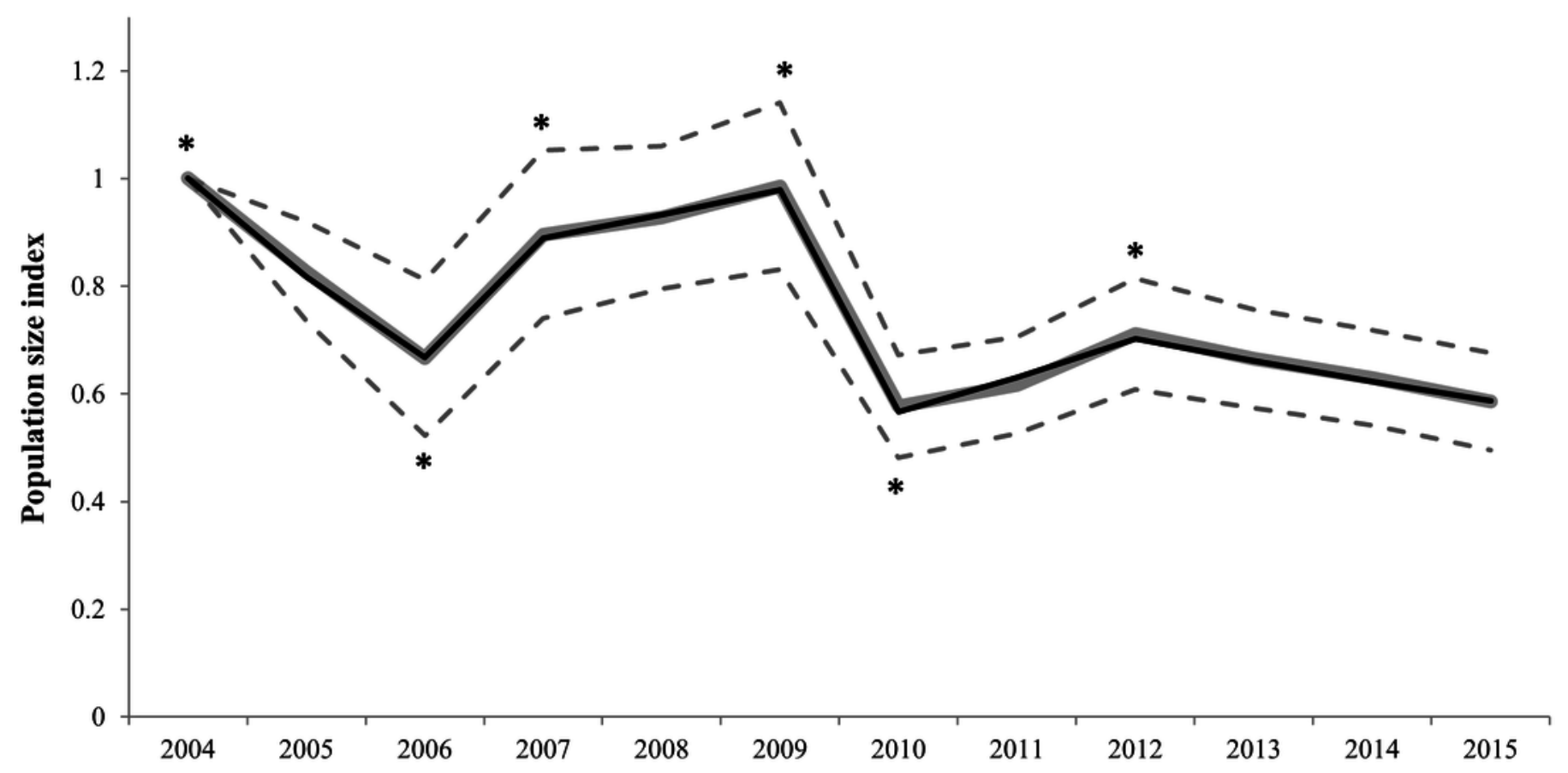




\section{Figure 3}

Imputed (grey continuous line) and predicted (black continuous line) population size indices estimated by Switching Linear Trend models during the 2004 - 2015 period for each Autonomous Community.

A) Andalusia; B) Aragon; C) Catalonia; D) Castile-Leon ; E) Castile-La Mancha; F) Community of Valencia; G) Navarre; H) Region of Murcia. Time-points incorporated in models as significant change-points on population trends are marked with asterisk (*). $95 \%$ Confidence Intervals (striped grey lines) are depicted. 

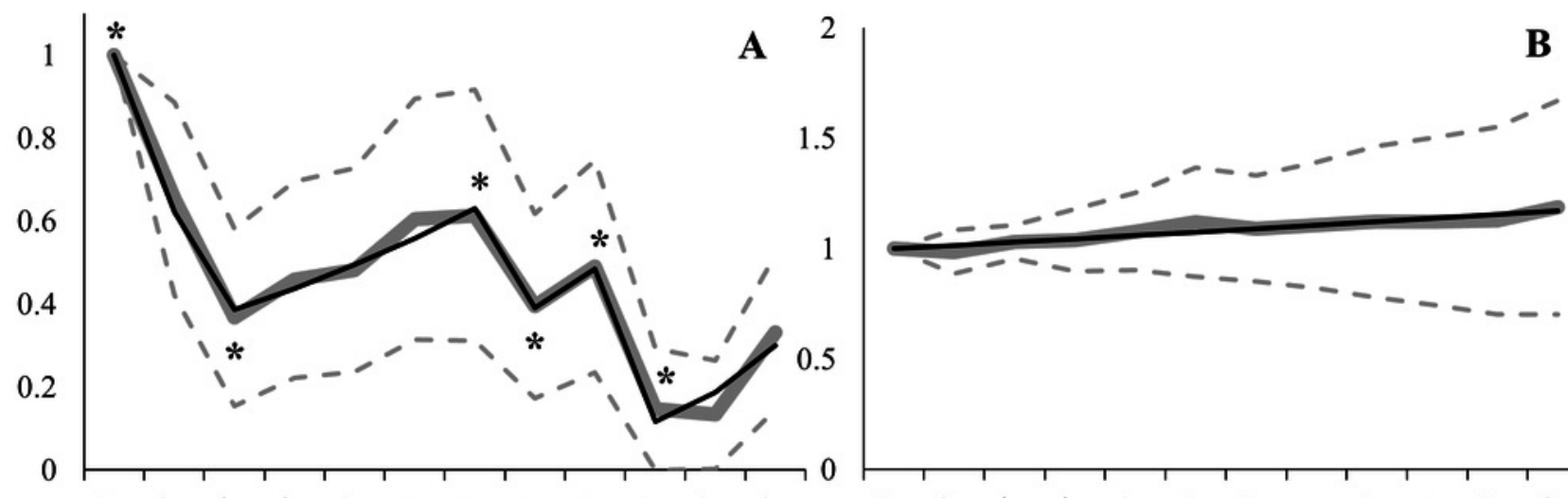

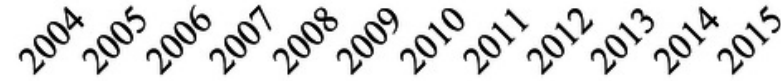
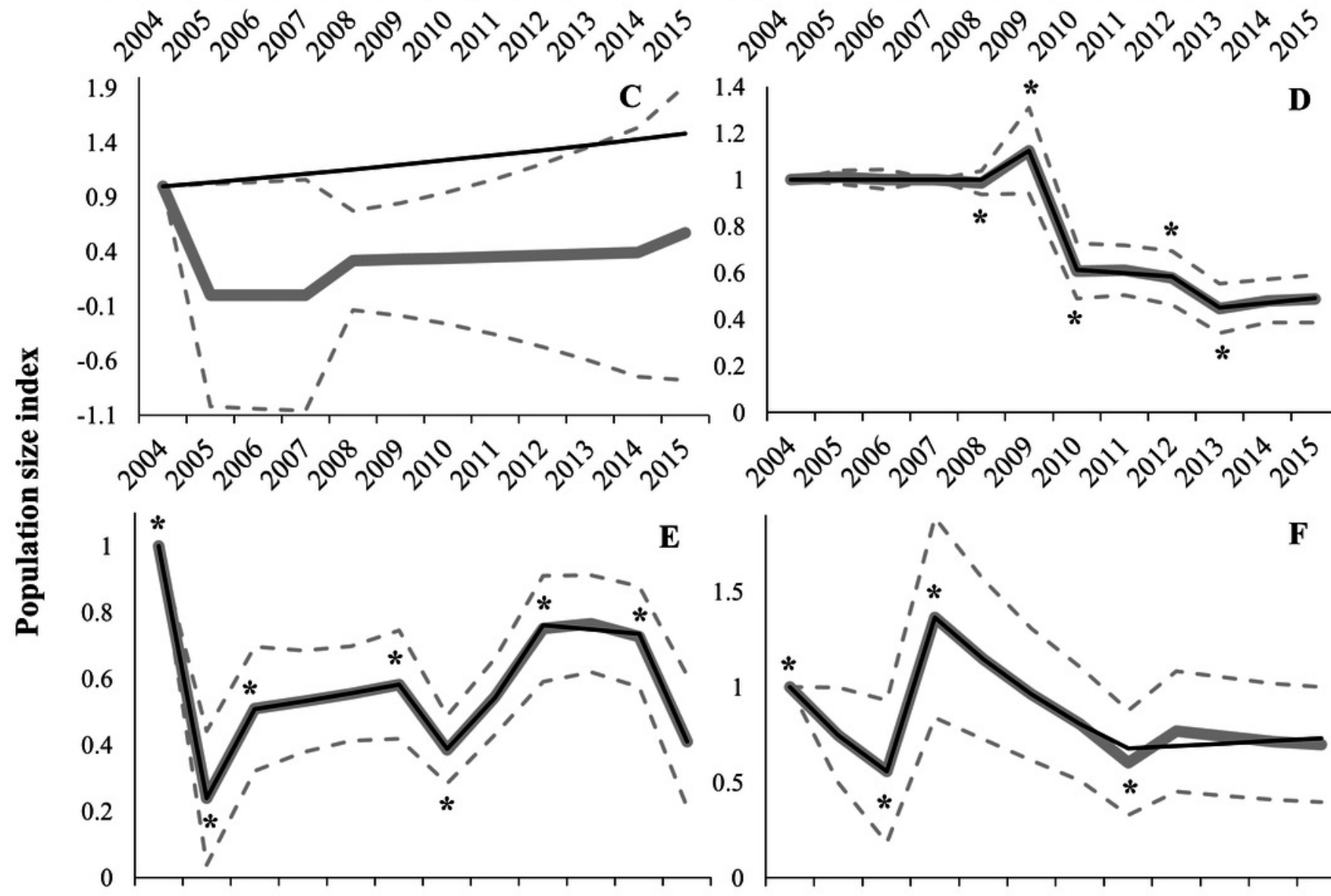

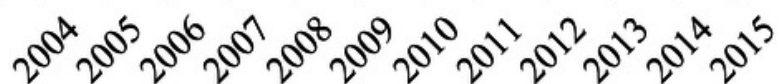

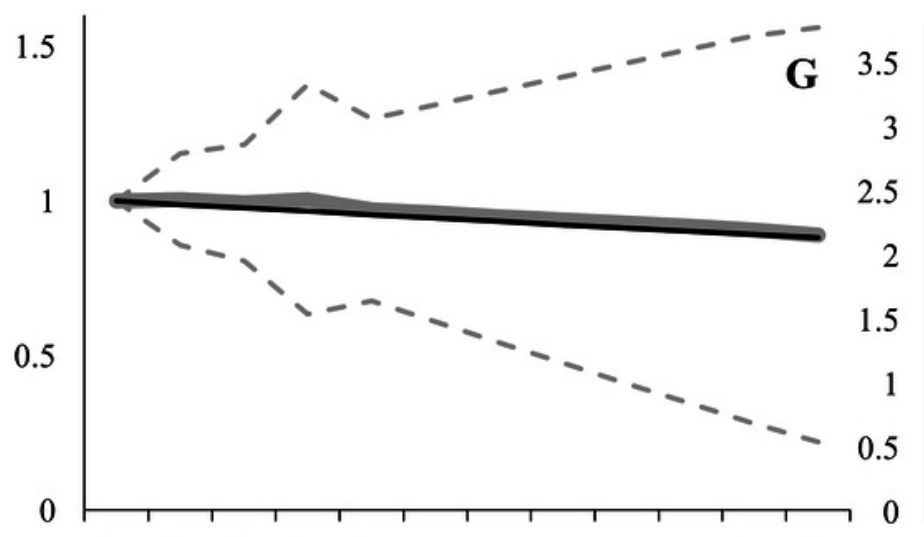

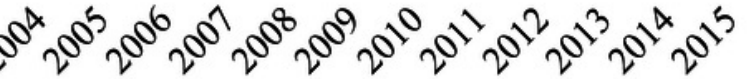

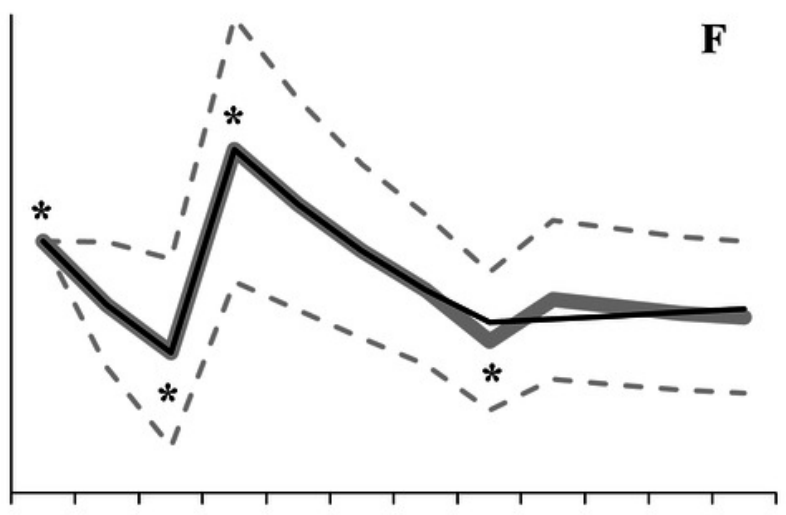

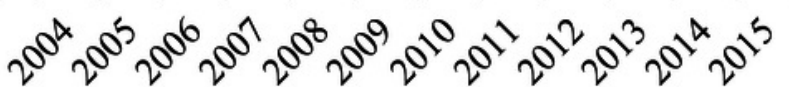
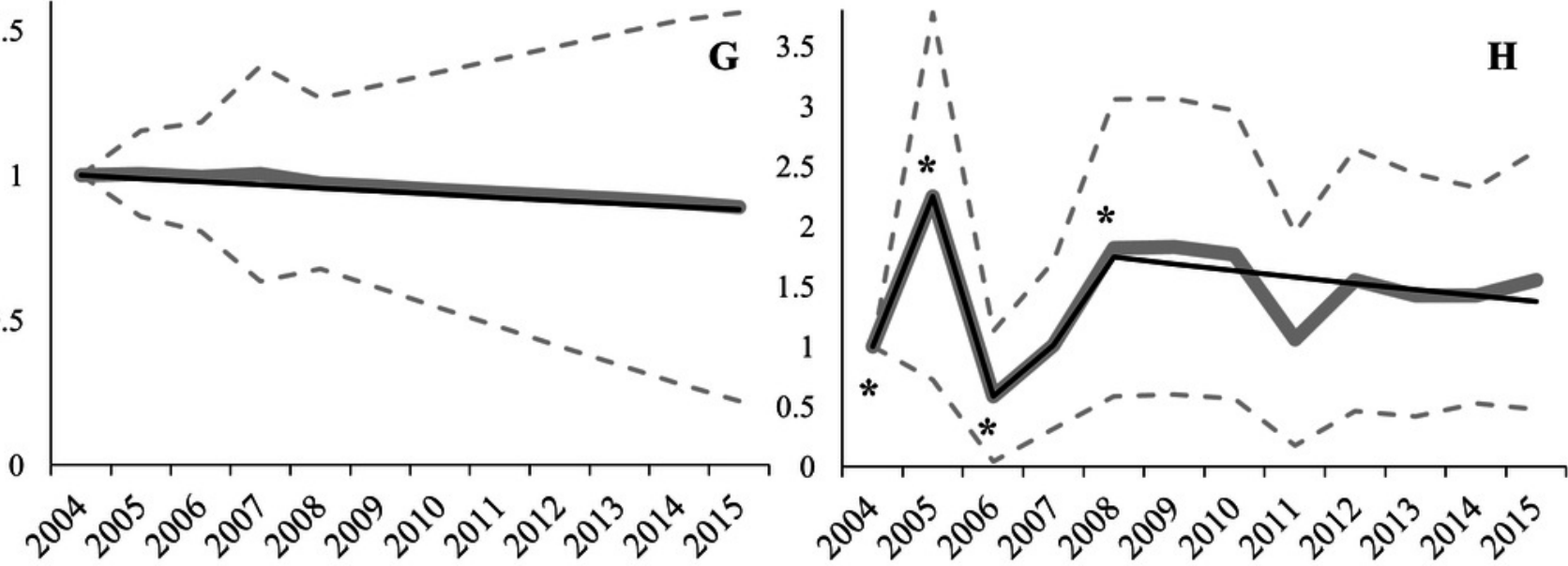

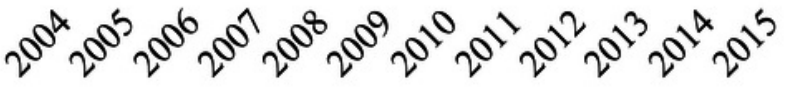




\section{Table $\mathbf{1}$ (on next page)}

Results of regional Switching Linear Trend models through the time series 2004-2015.

AN: Andalusia. AR: Aragon. CA: Catalonia. CL: Castile-Leon. CM: Castile-La Mancha. CV: Community of Valencia. NA: Navarre. RM: Region of Murcia. 


\begin{tabular}{|c|c|c|c|c|c|c|c|c|}
\hline & AN & $\mathrm{AR}$ & $\mathrm{CA}$ & $\mathrm{CL}$ & $\mathrm{CM}$ & $\mathrm{CV}$ & NA & RM \\
\hline Number of populations & 12 & 10 & 1 & 29 & 26 & 8 & 3 & 3 \\
\hline Local extinction events & 6 & 0 & 0 & 5 & 5 & 3 & 1 & 0 \\
\hline Missing values (\%) & 38.2 & 81.6 & 58.3 & 49.1 & 63.1 & 44.8 & 63.9 & 47.2 \\
\hline Annual change rate $(\%)$ & -10.9 & +1.5 & -8.7 & -8.4 & +1.5 & -2.5 & -1.1 & +2.6 \\
\hline $\begin{array}{l}95 \% \text { Confidence } \\
\text { Interval }\end{array}$ & {$[-16.2 ;-5.7]$} & {$[-2.3 ;+5.2]$} & {$[-35.5 ;+18.2]$} & {$[-10.0 ;-6.7]$} & {$[-2.1 ;+5.1]$} & {$[-5.7 ;+0.7]$} & {$[-7.9 ;+5.6]$} & {$[-2.2 ;+7.5]$} \\
\hline TRIM Trend ${ }^{\mathrm{a}}$ & $\begin{array}{c}\text { Steep } \\
\text { decline }\end{array}$ & Uncertain & Uncertain & $\begin{array}{l}\text { Steep } \\
\text { decline }\end{array}$ & Uncertain & Uncertain & Uncertain & Uncertain \\
\hline Wald-test change rate & - & - & 0.04 & - & - & - & - & - \\
\hline p-value & - & - & $>0.05$ & - & - & - & - & - \\
\hline \multicolumn{9}{|c|}{ Goodness-of-fit test } \\
\hline Chi-squared $(\chi 2)$ & 98.98 & 11.56 & - & 187.13 & 152.34 & 63.00 & 2.00 & 4.98 \\
\hline p-value $\chi^{2}$ & $0.0158 *$ & $>0.05$ & - & $<0.01$ & $<0.01$ & $0.0152 *$ & $>0.05$ & $>0.05$ \\
\hline Likelihood Ratio (LR) & 100.81 & 11.85 & - & 211.67 & 139.36 & 63.53 & 2.24 & 5.44 \\
\hline p-value LR & $0.0115^{*}$ & $>0.05$ & - & $<0.01$ & $<0.01$ & $0.0136^{*}$ & $>0.05$ & $>0.05$ \\
\hline AIC & -41.19 & -10.15 & - & -74.33 & -24.64 & -18.47 & -3.76 & -18.56 \\
\hline Overdispersion & 1.39 & 1.01 & 6.67 & 1.29 & 1.69 & 1.43 & 0.98 & 0.23 \\
\hline Serial correlation & 0.09 & -0.18 & -0.06 & 0.39 & 0.20 & 0.30 & - & 0.06 \\
\hline
\end{tabular}

1 P-values of accepted models are marked in bold

2 P-values of models near to acceptance threshold are marked with asterisk (*)

3 a Trend classification attending to TRIM criteria (Pannekoek and Van Strien 2006b) 


\section{Table 2 (on next page)}

Assessment of Dupont's lark threat category.

Overall and average annual change rate obtained from trend analysis, and current threat category at National and Regional Catalogues of Endangered Species are shown. In addition, population size change in a 10-year period and corresponding threat category attending to A1 and A2 criteria applicable in the SCTS (Resolution $6^{\text {th }}$ March 2017) are provided. The $95 \%$ Confidence Intervals are shown in brackets. Threat categories: Sensitive to Habitat Alteration (SHA), Vulnerable (VU) and Endangered (EN). AN: Andalusia. AR: Aragon. CA: Catalonia. CL: Castile-Leon. CM: Castile-La Mancha. CV: Community of Valencia. NA: Navarre. RM: Region of Murcia. 


\begin{tabular}{|c|c|c|c|c|c|c|}
\hline & $\begin{array}{l}\text { Overall change } \\
\text { rate (\%) from } \\
2004 \text { to } 2015\end{array}$ & $\begin{array}{c}\text { Average } \\
\text { annual change } \\
\text { rate }(\%)\end{array}$ & $\begin{array}{l}\text { Current } \\
\text { category } \\
\text { of threat }\end{array}$ & $\begin{array}{l}\text { Change rate for } \\
10 \text { years }(\%)\end{array}$ & $\begin{array}{c}\text { Category of } \\
\text { threat - A1 } \\
\text { criterion }\end{array}$ & $\begin{array}{c}\text { Category of } \\
\text { threat - A2 } \\
\text { criterion }\end{array}$ \\
\hline $\mathrm{AN}$ & $\begin{array}{c}-66.8 \\
{[-85.4 ;-48.2]}\end{array}$ & $\begin{array}{c}-10.9 \\
{[-16.2 ;-5.7]}\end{array}$ & $\mathrm{VU}^{\mathrm{a}}$ & $\begin{array}{c}-68.5 \\
{[-82.9 ;-44.4]}\end{array}$ & $\begin{array}{c}\mathrm{VU} \\
{[\mathrm{EN} ; \text { None] }}\end{array}$ & $\begin{array}{c}\mathrm{EN} \\
{[\mathrm{EN} ; \mathrm{VU}]}\end{array}$ \\
\hline $\mathrm{AR}$ & $\begin{array}{c}+18.7 \\
{[-29.7 ;+67.1]}\end{array}$ & $\begin{array}{c}+1.5 \\
{[-2.3 ;+5.2]}\end{array}$ & $\mathrm{SHA}^{\mathrm{b}}$ & $\begin{array}{c}+16.1 \\
{[-20.8 ;+66.0]}\end{array}$ & $\begin{array}{c}\text { None } \\
\text { [None; None] }\end{array}$ & $\begin{array}{c}\mathrm{VU}^{*} \\
{\left[\mathrm{VU}^{*} ; \mathrm{VU}^{*}\right]}\end{array}$ \\
\hline $\mathrm{CA}$ & $\begin{array}{c}-42.9 \\
{[-178.0 ;+92.2]}\end{array}$ & $\begin{array}{c}-8.7 \\
{[-35.5 ;+18.2]}\end{array}$ & - & $\begin{array}{c}+42.4 \\
{\left[-98.3 ;+2.9 \cdot 10^{3}\right]}\end{array}$ & $\begin{array}{c}\text { None } \\
\text { [EN; None] }\end{array}$ & $\begin{array}{c}\mathrm{VU}^{*} \\
{\left[\mathrm{EN} ; \mathrm{VU}^{*}\right]}\end{array}$ \\
\hline CL & $\begin{array}{c}-51.1 \\
{[-61.4 ;-40.8]}\end{array}$ & $\begin{array}{c}-8.4 \\
{[-10.0 ;-6.7]}\end{array}$ & - & $\begin{array}{c}-58.4 \\
{[-65.1 ;-50.0]}\end{array}$ & $\begin{array}{c}\text { VU } \\
\text { [VU; VU] }\end{array}$ & $\begin{array}{c}\mathrm{EN} \\
{[\mathrm{EN} ; \mathrm{EN}]}\end{array}$ \\
\hline $\mathrm{CM}$ & $\begin{array}{c}-59.0 \\
{[-78.9 ;-39.1]}\end{array}$ & $\begin{array}{c}+1.5 \\
{[-2.1 ;+5.1]}\end{array}$ & $\mathrm{VU}^{\mathrm{c}}$ & $\begin{array}{c}+16.1 \\
{[-19.1 ;+64.4]}\end{array}$ & $\begin{array}{c}\text { None } \\
\text { [None; None] }\end{array}$ & $\begin{array}{c}\mathrm{VU}^{*} \\
{\left[\mathrm{VU}^{*} ; \mathrm{VU}^{*}\right]}\end{array}$ \\
\hline $\mathrm{CV}$ & $\begin{array}{c}-30.1 \\
{[-60.3 ;+0.1]}\end{array}$ & $\begin{array}{c}-2.5 \\
{[-5.7 ;+0.7]}\end{array}$ & $V_{U^{d}}$ & $\begin{array}{c}-22.4 \\
{[-44.4 ;+7.2]}\end{array}$ & $\begin{array}{c}\text { None } \\
\text { [None; None] }\end{array}$ & $\begin{array}{c}\mathrm{VU}^{*} \\
\text { [VU; VU*] }\end{array}$ \\
\hline NA & $\begin{array}{c}-11.0 \\
{[-78.0 ;+56.0]}\end{array}$ & $\begin{array}{c}-1.1 \\
{[-7.9 ;+5.6]}\end{array}$ & $\mathrm{SHA}^{\mathrm{e}}$ & $\begin{array}{c}-10.5 \\
{[-56.1 ;+72.4]}\end{array}$ & $\begin{array}{c}\text { None } \\
\text { [VU; None] }\end{array}$ & $\begin{array}{c}\mathrm{VU}^{*} \\
{\left[\mathrm{EN} ; \mathrm{VU}^{*}\right]}\end{array}$ \\
\hline $\mathrm{RM}$ & $\begin{array}{c}+55.2 \\
{[-52.4 ;+162.8]}\end{array}$ & $\begin{array}{c}+2.6 \\
{[-2.2 ;+7.5]}\end{array}$ & $V_{U^{f}}$ & $\begin{array}{c}+29.3 \\
{[-19.9 ;+106.1]}\end{array}$ & $\begin{array}{c}\text { None } \\
\text { [None; None] }\end{array}$ & $\begin{array}{c}\mathrm{VU}{ }^{*} \\
{\left[\mathrm{VU}^{*} ; \mathrm{VU}^{*}\right]}\end{array}$ \\
\hline Spain & $\begin{array}{c}-41.4 \\
{[-50.5 ;-32.4]}\end{array}$ & $\begin{array}{c}-3.9 \\
{[-4.9 ;-2.8]}\end{array}$ & VU & $\begin{array}{c}-32.8 \\
{[-39.5 ;-24.7]}\end{array}$ & $\begin{array}{c}\text { None } \\
\text { [None; None] }\end{array}$ & $\begin{array}{c}\text { VU } \\
\text { [VU; none] }\end{array}$ \\
\hline $\begin{array}{l}{ }^{\mathrm{a}} \text { Decre } \\
{ }^{\mathrm{b}} \text { Decre } \\
{ }^{\mathrm{c}} \text { Decre } \\
{ }^{\mathrm{d}} \text { Decr } \\
{ }^{\mathrm{e}} \text { Decre } \\
{ }^{\mathrm{f}} \text { Law } 7 \\
\text { * Mini } \\
\text { Decem }\end{array}$ & $\begin{array}{l}23 / 2012 \text { of } 14 \mathrm{Fel} \\
49 / 1995 \text { of } 28 \mathrm{Mr} \\
33 / 1998 \text { of } 5 \mathrm{Ma} \\
32 / 2004 \text { of } 27 \mathrm{Fe} \\
563 / 1995 \text { of } 27 \mathrm{~N} \\
995 \text { of } 21 \text { April } 1 \\
\text { um category of th }\end{array}$ & $\begin{array}{l}\text { uary } 2012 \\
\text { ch } 1995 \\
1998 \\
\text { ruary } 2004 \\
\text { vember } 1995 \\
95\end{array}$ & & & & h \\
\hline
\end{tabular}

